\title{
Conservation Status of Agarwood-Producing Species (Gyrinops versteegii) in Indonesia
}

\author{
Sutomo $^{1 *}$, Rajif Iryadi ${ }^{1}$, I Made Sumerta ${ }^{2}$ \\ ${ }^{1}$ Spatial Ecology Laboratory. Research Centre for Plant Conservation and Botanic Garden, \\ Indonesian Institute of Sciences (LIPI), Indonesia \\ ${ }^{2}$ Bali Botanical Garden, Indonesian Institute of Sciences (LIPI), Indonesia \\ *Corresponding Author: tommo.murdoch@gmail.com
}

Submitted: 2020-12-17. Revised: 2021-02-07. Accepted: 2021-07-27

\begin{abstract}
Aquilaria malaccensis and Gyrinops versteegii are agarwood producing plant species that is widely used because of its fragrance. Gyrinops versteegii has not been much cultivated and along with the decreasing population of G. versteegii in its natural habitat. This study aimed to assess scarcity status of Gyrinops versteegii based on distribution records from both herbarium and field exploration to assist the formulation of its conservation policy. Distribution data were obtained from online database and also from field exploration in Lombok, Sumbawa, and Flores Islands to obtain the population information. Area of Occupancy (AOO) and Extent of Occurrence (EOO) were calculated using GeoCAT (Geospatial Conservation Assessment Tool) and IUCN status recommendation was discussed. The estimated EOO was $868,422,919 \mathrm{~km}^{2}$, exceeding the value required for the threatened category. Based on EOO, it is included in the Least Concern (LC) category, but the EOO covers a large area of the ocean so the AOO was $116 \mathrm{~km}^{2}$ as meets criterion B $\left(\mathrm{AOO}<500 \mathrm{~km}^{2}\right)$. It can be categorized into endangered $(\mathrm{EN})$. Population data and conservation status of $G$ verstegii are very important to provide recommendations on the quota wild-harvesting of agarwood by stakeholders.
\end{abstract}

Key words: conservation; agarwood; Gyrinops; geocat; Flores

How to Cite: Sutomo, , Iryadi, R., \& Sumerta, I. M. (2021). Conservation Status of Agarwood-Producing Species (Gyrinops versteegii) in Indonesia. Biosaintifika: Journal of Biology \& Biology Education, 13(2), 149-157.

DOI: http://dx.doi.org/10.15294/biosaintifika.v13i2.27809

\section{INTRODUCTION}

Agarwood, likewise sandalwood is a forest product that is widely used because of its fragrance. Many think that agarwood and sandalwood are produced from the same plant (Isnaini, 2008). Sandalwood is produced from sandalwood trees (Santalum album) from the Santalaceae family, while agarwood is a non-timber forest product produced from several tree species from several genera of the Thymelaeaceae family (Karlinasari et al., 2015)Agarwood is a resin or a kind of sap that is produced from some infected tree species (agarwood producer). Agarwood which is also widely known as sapwood, karas, mengaras, alim, rakes, sigsigi, gaharu, aloeswood, oud, eaglewood and others, has long been used in traditional Chinese medicine (Barden et al., 2000) Various types of agarwood are grown in Indonesia. It is known that there are about 26 species from seven genera that grow in natural forests, namely Aetoxylon, Aquilaria, Enkleia, Gonystylus, Gyrinops, Phaleria and Wikstroemia. Of the seven genera, the Aquilaria, Gyrinops, and Gonystylus are the most utilized genera (Susilo et al., 2014). One of them that will be discussed in this paper is the Gyrinops versteegii. It is a tree that can reach up to $10 \mathrm{~m}$ in height, $25-30 \mathrm{~cm}$ in diameter, and has various leaf morphologies (Surata \& Soenarno, 2011).

Aquilaria filaria and Aquilaria malaccensis have been widely known by the public and have been widely cultivated. In the IUCN Red list, Aquilaria malaccensis is included in the critically endangered (CR) category (Harvey-Brown, 2018). On the other hand, Gyrinops versteegii is starting to be sought after as a type of agarwood producer other than Aquilaria. Agarwood in nature has a very high market demand, interest in natural agarwood has resulted in natural agarwood stocks being threatened with extinction. Ideally, the agarwood harvested is agarwood that produces gubal, but in the real condition, whatever agarwood trees are still cut down. This existence made the parent trees in nature limited and the seedling rare toolt has not been much cultivated and along with the decreasing natural $G$. versteegii in its habitat, causing concern about the future of this species.

Based on Indonesian Secretariate of Biodiversity Scientific Authority the quota for wild collecting of Gyrinops sp. in Papua Province in 2019 is $750,000 \mathrm{~kg}$ and in NTT Province the proposal for 2021 is proposed for $100 \mathrm{~kg}$ (personal communication). However, on the other hand, efforts and studies to find out the current condition of the distribution and population of $G$. versteegii are are still very rarely 
carried out, let alone to know the updating of its conservation status from field data. The populations recorded from Lesser Sunda Island, especially Western Sumba, Alor Island, Lombok Island, and Flores Island, to Sulawesi, Mollucas, and Papua were reported to decline continuously because of hard harvesting of mature plants especially in Nusa Tenggara Barat and Nusa Tenggara Timur Provinces (Herber, 2003; Rindyastuti et al., 2019). The limited area are caused by land cover conversion and the opening of land forest to be traditional farming that has been burning the land frequently in Flores (Fiqa \& Oktavia, 2020).

This population is decreasing in the wild so that the Indonesian government has a policy to take the trading quota of $G$. versteegii in Appendix II CITES (Convention on International Trade in Endangered Species) (Dwianto et al., 2019; Rindyastuti et al., 2019). This species in nature itself is one of the threatened plant species (Susilo et al., 2014). Unlike Aquilaria species, G. versteegii has not yet been included in the IUCN Red-list. According to IUCN this species is Not Evaluated and Data Deficient (IUCN, 2020).

IUCN has provided relevant criteria for all species in the world to evaluate the conservation status of a species. The purpose of this categorization is to give the world public awareness of the importance of conservation and to help policy makers to improve the conservation status of species that are already on the IUCN red list (Widodo et al., 2011). GeoCAT (Geospatial Conservation Assessment Tool) is a web based application that can be used to determine the conservation status. Not many agarwood species has been assessed with this application, in this case, Gyrinops versteegii. It is hoped that with the results of the assessment of the conservation status of $G$. versteegii species, the public will be more aware of the importance of conservation of this agarwoodproducing plant. In fact, not just agarwood production, this agarwood plant also has been used as other utilization including handicrafts, therefore ethnobotanical notes on this species is also a good addition to the G. versteegii data. This paper aimed to assess the scarcity status of Gyrinops versteegii agarwood-producing species based on distribution data records from both herbarium and field results to assist in the formulation of its conservation strategy.

\section{METHODS}

\section{Data source and tools}

Past occurences record of $G$. verstegii was obtained from the Global Biodiversity Information Facility or GBIF (GBIF Secretariat, 2021https://www.gbif.org/species/3568490). These information was used to choose the Gyrinops versteegii data (distribution, population, and macroclimate) (García-Roselló et al., 2015). There have been found 25 occurrences records, but there are only 3 records with geo-references, i.e. one on Lombok Island and two in Papua Province. From direct searches at the Hortus Botanicus Baliense in the Bali Botanic Garden, we examined the HK.762 specimen dated July 3, 2006 with the sampling location in West Lombok but the coordinates are missing. From an online search at the National Herbarium Nederland Universitet Leiden, herbarium specimen G. versteegii number L.0830233 mentions that this species was found in forests in West Sumbawa (missing coordinates) in 1993.

\section{Field study}

Field exploration was conducted on 2018 and 2019 in NTB and NTT (Figure 1) to find out the latest distribution of both cultivated and natural $G$. versteegii. Handheld Garmin GPS was used to record the geographic coordinates of $G$. versteegii. Specimens (evidence of exploration) were stored in the Herbarium Hortus Botanicus Baliensis, "Eka Karya" Bali Botanical Garden in Bedugul. An ethnobotanical note of $G$. versteegii from the field was obtained by conducting open interview to key informant.

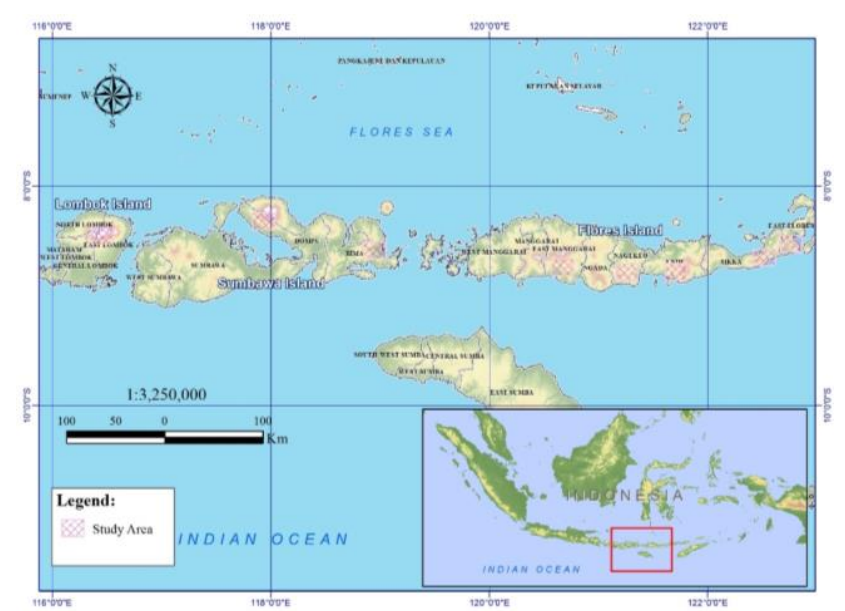

Figure 1. Field study locations to record Gyrinops versteegii data.

\section{Data base analysis}

Geographical and ecological data resulting from field exploration are invaluable sources of information for EOO, AOO, and fragmentation. AOO (Area of Occupancy) is the area occupied by taxons in the more common Extent of Occurrence (EOO) (IUCN 2012), and is usually used as a measure of species distribution. AOO species is one of the more commonly used parameters in IUCN Red List assessments. Specific measurements of the 
geographic range of species (EOO) and $\mathrm{AOO}$ are used in assessing the IUCN Red List based on Criterion B. The area of Occupancy (AOO) used in the analysis is based on the rules of the IUCN with a grid cell width of $2 \mathrm{~km}$ (IUCN, 2012).

GeoCAT (Geospatial Conservation Assessment Tool) was used to determine AOO and EOO. The GeoCAT is a web-based application tool that uses primary biological data for semi-automatic IUCN Red List assessment and analysis (Bachman \& Moat, 2012). This web-based tool is an open source for fast geospatial analysis to facilitate the self-assessment of Red List species (Bachman et al., 2011). The web address is available at https://www.kew.org/science/ourscience/projects/geocat-geospatial-conservationassessment-tool. All coordinate points from the encounter with $G$. versteegii in the field during exploration were entered into GeoCAT. Likewise, the coordinate points obtained from the herbarium search results and the GBIF. Then, to get an overview of $\mathrm{EOO}$ and $\mathrm{AOO}$, the enable EOO / AOO button was selected in the application. The application was automatically draw the polygon and calculate the area of EOO and AOO along with the recommended conservation status. The analysis results were saved (in GEOCAT file format) to be processed further.

\section{RESULTS AND DISCUSSION}

\section{Taxonomy note}

The descriptions of the living and herbarium collections (Figure 2) from Gyrinops versteegii at the Bali Botanic Garden show the following descriptions: The stems are brown, sometimes some are white; tree height can reach $12 \mathrm{~m}$; the leaf size is about $4 \mathrm{~cm}$ wide by about $13 \mathrm{~cm}$ long; single leaf; incomplete leaves; alternate leaves; the edges of the leaves are flat; elongated leaf shape; the tip of the leaf is tapered; dark green leaf color; glossy smooth leaf surface; flowers in tubular or funnel-shaped with 5-6 crowns; axillary flower; panicles; androgynous flower. The fruit is oval and fleshy (Figure 2). The color of the young fruit is green, after being old it becomes reddish yellow, and will break off by itself.
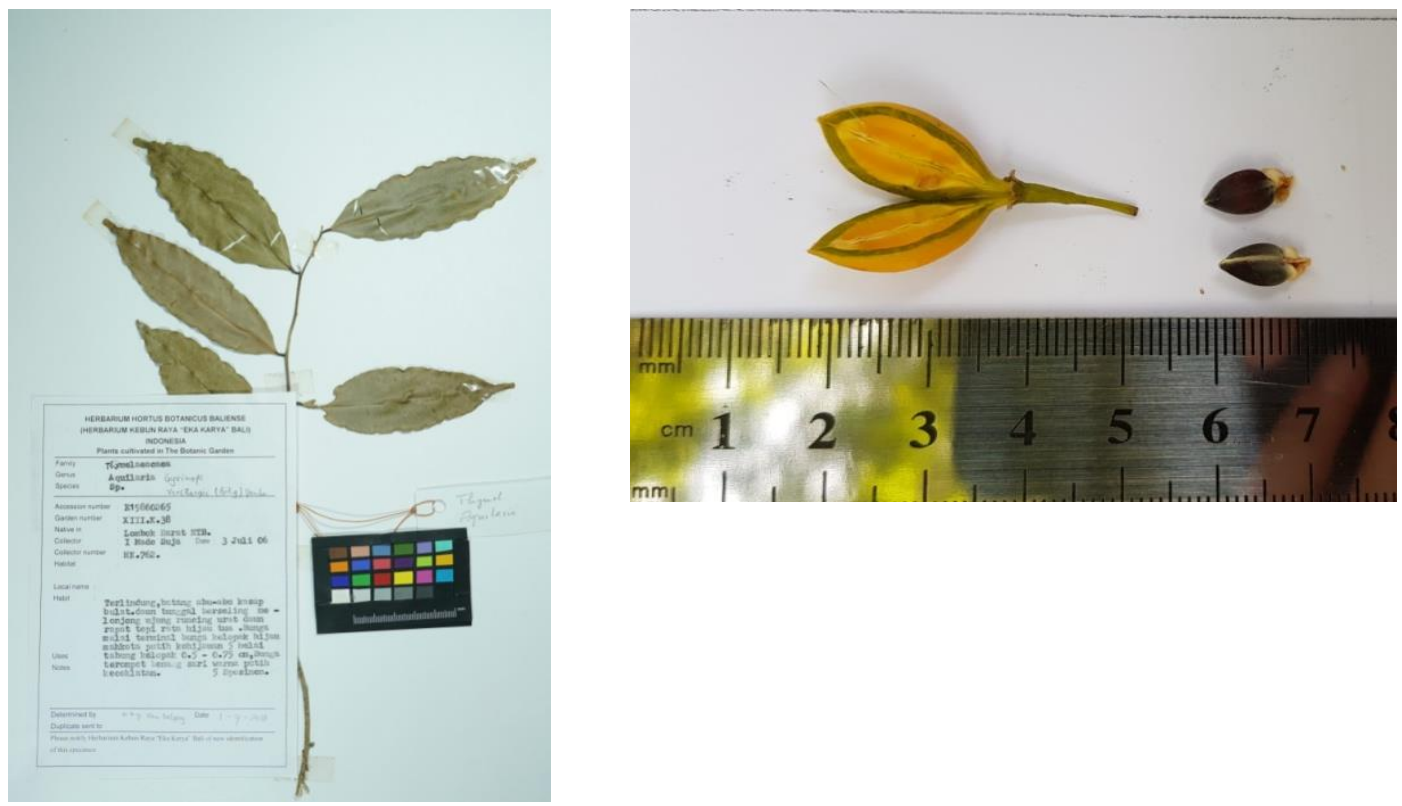

Figure 2. Herbarium Gyrinops versteegii in the Hortus Botanicus Baliensis (Left); Gyrinops versteegii fruit and seeds from exploration on Lombok Island, NTB 2018 (right)

\section{Habitat Ecology}

Habitat data together with distribution data are two very important things in the effort to conserve Gyrinops versteegii species. Gyrinops spp. distribution data collection obtained from the field survey (Figure 3) were recorded for their position using GPS (Table1). Microclimate as well as topographic data of Gyrinops versteegii habitat were also recorded. From the results of these field exploration activities, we found the distribution of $G$. versteegii which is mostly cultivated by the community (only a few $G$. versteegii were found in natural forests). From the results of our field observations on the island of Lombok, it was known that in general the $G$. versteegii observation plots were located at an altitude of $100-900 \mathrm{~m}$ asl, the slope of the soil ranged from $0-18^{\circ}$, with a soil $\mathrm{pH}$ of 6 - 6.5, they had an air temperature ranging from 26 $31^{\circ} \mathrm{C}$, relative humidity around $70-80 \%$ with a sunlight intensity of $300-10000$ lux. The results of the ordination analysis also showed that $G$. versteegii was thought to have a correlation with soil $\mathrm{pH}$, soil 
moisture, sunlight intensity, and air temperature (Roemantyo \& Partomihardjo, 2010; Sitepu et al., 2011; Sutomo \& Oktavia, 2019). Refer to Yulistyarini et al. (2020), the distribution of $G$. versteegii has a strong correlation between the content of C organic and Soil Organic Matter (SOM) in Manggarai - Flores. This condition makes an indication that the preference location of G. versteegii is the fertile soil naturally.

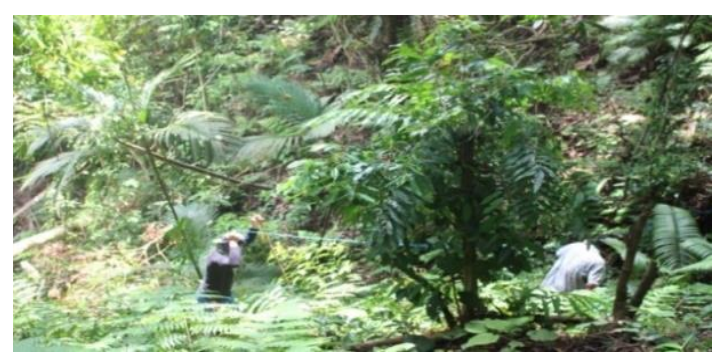

Figure 3. Field exploration activities to determine the distribution and population of Gyrinops versteegii in NTB and NTT. Making a plot at the location in which $G$. versteegii was found.

Table 1. Location and recording coordinates of the exploration results of Gyrinops versteegii in NTB and NTT

\begin{tabular}{|c|c|c|c|}
\hline Longitude $\left({ }^{\circ}\right)$ & Latitude $\left({ }^{\circ}\right)$ & Altitude ( $\mathrm{m}$ asl) & Location \\
\hline 120.67973111100 & -8.76364000000 & 432 & East Manggarai, Flores Island \\
\hline 120.69359388900 & -8.74995305556 & 601 & East Manggarai, Flores Island \\
\hline 120.69359388900 & -8.74995305556 & 741 & East Manggarai, Flores Island \\
\hline 120.69359388900 & -8.74995305556 & 741 & East Manggarai, Flores Island \\
\hline 120.70899305600 & -8.76177111111 & 841 & East Manggarai, Flores Island \\
\hline 120.70894305600 & -8.76182500000 & 841 & East Manggarai, Flores Island \\
\hline 121.19223194400 & -8.85339194444 & 499 & Nagekeo Flores \\
\hline 121.19197305600 & -8.85337194444 & 499 & Nagekeo Flores \\
\hline 121.19192388900 & -8.85325611111 & 499 & Nagekeo Flores \\
\hline 121.19187611100 & -8.85301194444 & 499 & Nagekeo Flores \\
\hline 122.73164694400 & -8.51773500000 & 306 & East Flores, Flores Island \\
\hline 122.73216388900 & -8.51837500000 & 306 & East Flores, Flores Island \\
\hline 122.73291805600 & -8.52022611111 & 315 & East Flores, Flores Island \\
\hline 122.73951500000 & -8.52498000000 & 392 & East Flores, Flores Island \\
\hline 122.74068111100 & -8.52541111111 & 410 & East Flores, Flores Island \\
\hline 122.43284694400 & -8.68820111111 & 878 & Sikka, Flores Island \\
\hline 122.43497305600 & -8.69097111111 & 862 & Sikka, Flores Island \\
\hline 122.44237805600 & -8.69610694444 & 725 & Sikka, Flores Island \\
\hline 122.44237611100 & -8.69666888889 & 708 & Sikka, Flores Island \\
\hline 122.44127500000 & -8.69811500000 & 678 & Sikka, Flores Island \\
\hline 122.43659805600 & -8.69846500000 & 659 & Sikka, Flores Island \\
\hline 121.81395000000 & -8.69595000000 & 1104 & Ende, Flores Island \\
\hline 116.55880845200 & -8.51046002470 & 922 & East Lombok, Lombok Island \\
\hline 116.46584250000 & -8.49849125370 & 925 & East Lombok, Lombok Island \\
\hline 116.54835311700 & -8.51557902060 & 466 & East Lombok, Lombok Island \\
\hline 116.55032663600 & -8.52253591642 & 440 & East Lombok, Lombok Island \\
\hline 116.07757908300 & -8.46609746106 & 423 & North Lombok, Lombok Island \\
\hline 116.07741924000 & -8.46622017212 & 427 & West West Lombok, Lombok Island \\
\hline 116.08879214200 & -8.46562857740 & 384 & West Lombok, Lombok Island \\
\hline 116.08804305100 & -8.46628236584 & 342 & West Lombok, Lombok Island \\
\hline 116.08614714800 & -8.46763210371 & 393 & North Lombok, Lombok Island \\
\hline 116.07910140400 & -8.46637263894 & 422 & North Lombok, Lombok Island \\
\hline 116.07761965100 & -8.46609410830 & 388 & North Lombok, Lombok Island \\
\hline 116.08039096000 & -8.46633274108 & 405 & Central Lombok, Lombok Island \\
\hline 116.29279702000 & -8.55700255372 & 435 & Central Lombok, Lombok Island \\
\hline 119.00788600000 & -8.53572800000 & 50 & Bima, Sumbawa \\
\hline
\end{tabular}




\begin{tabular}{llll}
119.11138200000 & -8.67909500000 & 793 & Bima, Sumbawa \\
118.84692600000 & -8.52445400000 & 388 & Bima, Sumbawa \\
118.83834500000 & -8.64498900000 & 626 & Bima, Sumbawa \\
117.80975400000 & -8.18689500000 & 474 & Dompu, Sumbawa \\
\hline
\end{tabular}

\section{Ethnobotanical note}

Various uses of agarwood still revolves around its use as seeds, wood to be sold or distilled, and medicine that haven't been too well socialized by society (Mulyaningsih et al., 2017). Naturally, agarwood sold in the market has various grade and price. The level of quality/grade of agarwood so far can be tested with image analysis using the spectral grayscale on its images (Qomariyah et al., 2019). One of the agarwood farmers in East Manggarai stated that he did not want to use the agarwood injection method in an effort to produce agarwood, but only used mechanical methods with only injuries. One of the reasons why they did not choose to use the injection method was because they did not want the G. versteegii tree to be exposed to chemicals because these farmers also used the bark and the leaves as raw materials for making traditional liniment. One of the ingredients of the liniment are the bark and the leaves of agarwood plant plus a mixture of other spices (19 types of spices). The agarwood farmer has also attended training from the Indonesian Food and Drug Research Institute (BPOM), and now his traditional medicine is in the process of making a permit. One pack of liniment is sold for around 30 to 50 thousand rupiah. In addition to liniment, the farmer also makes handicrafts from G. versteegii wood in the form of a set of glasses and others (Figure 4) which are used to serve guests typical Flores drinks (moke/ sopi). From this explanation, it can be concluded that agarwood plays an important role in the source of livelihood for some residents of the Flores community. The utilization of Gyrinops versteegii in Sumbawa tends to have fewer uses apart from its wood for sale. In Sumbawa, it is known to be used as traditional medicine however this information is lacking in the literature (Sukenti \& Mulyaningsih, 2019).
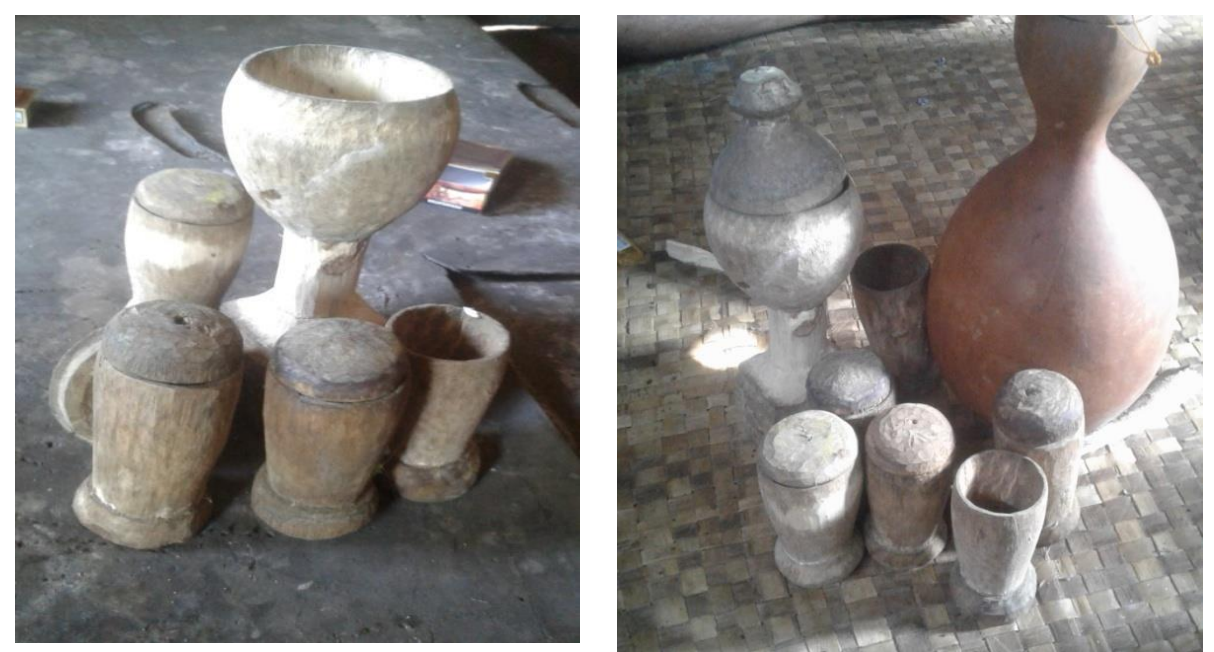

Figure 4. Handicrafts in the form of drinking sopi/moke tools made of Gyrinops versteegii wood on the island of Flores

\section{Current population trend}

From the results of our field search on three islands, namely Lombok, Sumbawa and Flores, it is known that most of the existing agarwood are cultivated by the community. The highest number of agarwood was found on the island of Flores, followed by Sumbawa and Lombok (Figure5).

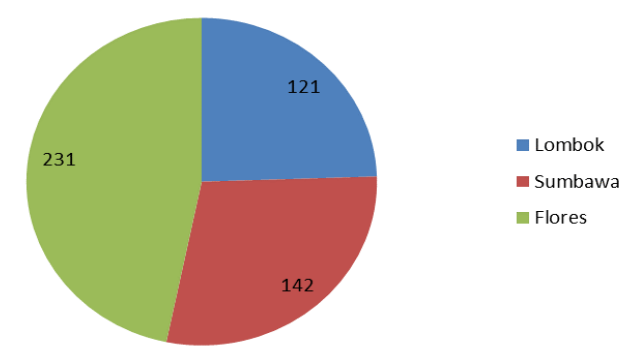

Figure 5. Proportion of the number of cultivated Gyrinops versteegii individuals found at the exploration site 
In Lombok, people are familiar with agarwood from the G. versteegii species. Based on the stories of the elders, it was known that many Lombok people in the past were looking for natural agarwood in the forest. But now the existence of agarwood that grows naturally in the forest is very difficult to find. From the results of our search on the island, natural agarwood can only be found in Mount Rinjani Resort Aikmel National Park and even then only two individuals. The natural agarwood population is decreasing from year to year. To overcome the scarcity of $G$. versteegii along with forest destruction on the island of Lombok, the Government has implemented a reforestation program through the Forestry Service and other relevant agencies. The $G$. versteegii planting program was carried out in 19992006 at BKPH Rinjani Barat (personal communication, 2018) by the Forest Service; 19972001 in the Senaru Educational Forest by the University of Mataram and BPDAS Dodokan Mulyosari; 1997-2006 at KHDTK Rarung Research Forest by the Ministry of Forestry. The previous study also stated that the planting status of $G$. versteegii found in the research location is dominated by production plants owned by residents (Sutomo \& Oktavia, 2019).

According to the story of local community member in Manggarai, Flores Island, since 1978, the trend of the community is looking for agarwood in the forest. Natural agarwood that grows naturally in the forest is extracted by means of cutting. This possibility is one of the causes of the increasing scarcity of natural agarwood trees in forests in Flores in general today. For the record, agarwood that grows in natural forest is Gyrinops versteegii, with the local name Sukka. There is one G. versteegii tree which is thought to have grown naturally (possibly due to being spread by birds or otherwise) growing on the slopes of the Bukit Sandang cliff forest in East Manggarai Regency, Flores Island. Other agarwood we encountered in Flores were the result of planting by the community as a cultivated plant (Iryadi et al., 2021). Gyrinops versteegii could be classified into slow-growing species because the diameter increment is $0.5 \mathrm{~cm} /$ year and the cultivated $G$. versteegii was grown faster than the natural one (Dwianto et al., 2019).

On the island of Sumbawa, apart from the agarwood that is on the land owned by the residents, we also found agarwood that grows wild/naturally in natural forests of Alas Saboke in Lambu Village, Lambu District, Bima Regency. At this location, we found nine natural agarwood trees with an average diameter of $8 \mathrm{~cm}$ with an average height of about 7 $\mathrm{m}$. There were six seedlings at the site and no $G$. versteegii fruit was found. From the records of other researchers, it is also known that in Sumbawa, natural G. versteegii has been found at an altitude of 400-800 $\mathrm{m}$ asl from Mount Doro Tambiung in West Sumbawa to Mount Doro Saboke in East Sumbawa (Mulyaningsih \& Yamada, 2007).

\section{Conservation status assessment}

From the analysis using GeoCAT, it was found that the estimated Extent Of Occurrence (EOO) was $868,422,919 \mathrm{~km}^{2}$, exceeding the value required for the threatened category. According to the EOO, Gyrinops versteegii is included in the Least Concern (LC) category; however, the distribution was not continuous within the imaginary boundary, which can be drawn to include all occurrences of this species. In addition, the EOO as shown in the Figure 6 covers a large area of the ocean. Area Of Occupancy (AOO) of this species was $116 \mathrm{~km}^{2}$. It meets criterion $\mathrm{B}$, (estimated AOO of less than $500 \mathrm{~km} 2$ ) (IUCN, 2012). It is therefore considered to be at very high risk of extinction in the wild (EN). In other words, we can say that the value of $\mathrm{AOO}$ is considered more reliable. Therefore the category of the calculation of AOO can be used as a parameter to decide the conservation status of $G$. verstegii.

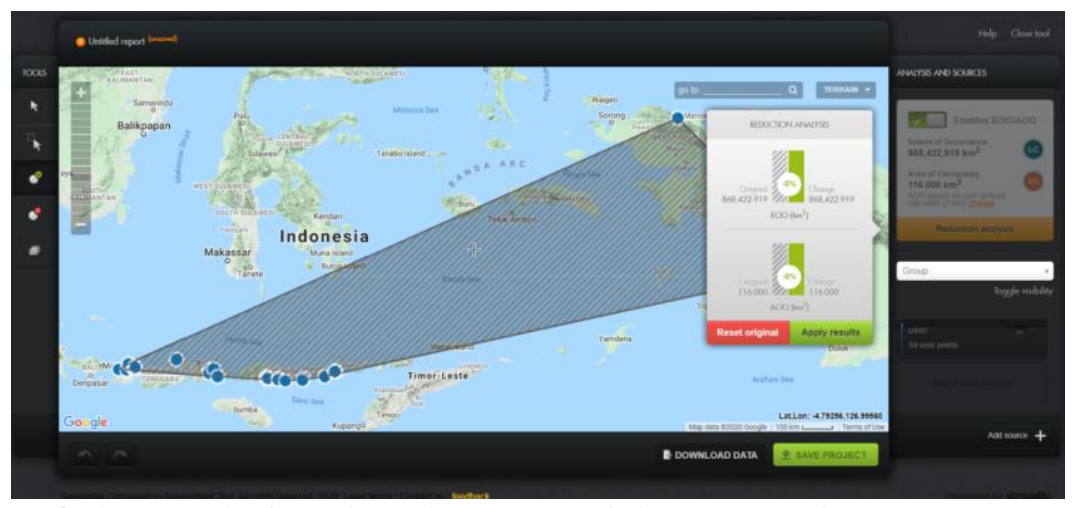

Figure 6. Results of data analysis using the Geospatial Conservation Assessment Tool / GeoCAT http://geocat.kew.org/ 
The number of locations and the continued decline of natural agarwood ( $G$. versteegii) is not certain because of the three natural sub-populations we found from our fieldwork, two were inside the protected areas (Lombok and Sumbawa) and one was outside the protected areas (Flores). However, natural $G$. versteegii may or may not occur outside of these three areas where threats are more intense and natural habitat decline continues. From sampling the natural agarwood population in the field, we estimate that the population is small and is thought to be included in the endangered category under criterion $\mathrm{C}$ with a total number of less than 2,500 individuals and possibly less than 250 adults in each subpopulation. It can be concluded that the conservation status of Gyrinops versteegii can be categorized into endangered (EN) EN - Endangered, C2a (i) (IUCN version 3.1). GeoCAT is a very useful tool in aiding to assess conservation status of a targeted species. The GeoCAT has also been used in various assessment of different species such as the tree fern Cibotium which is included in the threatened category in Indonesia (Praptosuwiryo, 2020).

\section{Conservation efforts}

According to Roemantyo \& Partomihardjo (2010), field data and herbarium collections of agarwoodproducing plant species collected after the 1970s were very limited. Only 7 species of data were recorded (including G. versteegii) by Partomihardjo \& Roemantyo from Herbarium Bogoriense, namely A. malaccensis, A. microcarpa, A. beccariana, A. hirta, A. cumingiana, A. filaria, G. versteegii, and $G$. ledermannii. This phenomenon can indicate whether the population of this species of agarwood is decreasing in its natural habitat in addition, data collection and research on the existence of natural gaharu species is also limited.. Even now, it is very likely that the population of agarwood producing species in their natural habitat is decreasing. This is because it is estimated that many natural habitats of these plants have changed their function from natural forests to other non-forest uses, such as settlements, transmigration, plantations/ agriculture, industrial areas, and so on (Roemantyo \& Partomihardjo, 2010).

In efforts to conserve $G$. versteegii species, it is necessary to analyze regional recommendations for cultivation as we have done for Flores Island (Sutomo \& Iryadi, 2018). The determination of this recommendation area is attempted as part of the planning in the cultivation of Gyrinops versteegii so that the planting can grow optimally and the results will be the same. In addition, conservation efforts of Gyrinops versteegii can also be carried out to prevent illegal logging of this plant in nature (Iryadi et al.,, 2021). For cultivation locations, we also pay attention to the status of the area, whether forested or not, in this case, a non-forest area is chosen. The process of preparing the directions for the cultivation area refers to field data regarding the conditions where these plants were found. For the character of land units we used the landform approach, as well as the classification of the elevation of areas and non-forest areas. By using a matching analysis with a binary approach, we overlaid three parameters, namely, land shape, elevation zoning, and class of non-forest areas (Sutomo \& Iryadi, 2018).

In addition, ex situ conservation efforts in the form of germplasm collection in a botanical garden are also needed. Apart from the five botanical gardens managed by the Indonesian Institute of Sciences (LIPI), the development of regional botanical gardens is currently being developed. In NTB, currently there is Lemor Botanical Garden in East Lombok. Meanwhile, in NTT, efforts are being made to build the Wolobobo Botanical Garden in Ngada, Flores Island.

Aquilaria filaria and Aquilaria malaccensis have been widely known by the public and have been widely cultivated. In the IUCN Red list, Aquilaria malaccensis is included in the critically endangered (CR) category (Harvey-Brown, 2018). On the other hand, although Gyrinops versteegii is starting to be sought after as a type of agarwood producer other than Aquilaria, it has not been much cultivated and along with the decreasing natural $G$ versteegii in its habitat, causing concern about the future of this species. As one of the native plants from East Indonesia area (GBIF, 2017), agarwood from wild is very wanted on the global market. Until now, detailed data on the status of its existence and conservation are limiting information (Sutomo \& Iryadi, 2019). Data population and conservation status are very important for input to provide information on the quota wild-harvesting of agarwood. This has used to be recommendation the conservation status of the species $G$. vertegii. Recommendations for the conservation status of $G$ versteegii are expected to provide input to stakeholders in the quota for taking this species in the wild and as an effort to cultivate this species by the surrounding community to prevent the threat of natural agarwood. It is hoped that with the results of the assessment of the conservation status of $G$. versteegii species, the public will be more aware of the importance of conservation of this agarwoodproducing plant.

\section{CONCLUSION}

Gyrinops versteegii can be recommended into EN (endangered) status in nature. This information is 
used as a recommendation in the quota of its wildharvesting status and there will be regulations for cultivated Gyrinops versteegii agarwood in terms of cultivation, processing, and marketing.

\section{ACKNOWLEDGEMENT}

We thank to Research Centre of Biology LIPICITES for funding this research. We appreciate various assistance from technicians and informants in the field and also botanist at the herbarium Hortus Botanicus Baliens

\section{REFERENCES}

Bachman, S., Moat, J., Hill, A. W., de la Torre, \& Ben Scott, J. (2011). Supporting Red List threat assessments with GeoCAT: geospatial conservation assessment tool. Retrieved 11/14/2020, 2020, from http://geocat.kew.org/

Barden, A., Anak, N. A., Mulliken, T., \& Song, M. (2000). Heart of the matter: agarwood use and trade and CITES implementation for Aquilaria malaccensis. Cambridge, UK.

Dwianto, W., Kusumah, S. S., Darmawan, T., Amin, Y., Bahanawan, A., Pramasari, D. A., Lestari, E., Himmi, S. K., Hermiati, E., Fatriasari, W., Laksana, R. P. B., Damayanti, R. (2019). Anatomical observation and characterization on basic properties of Agarwood (Gaharu) as an Appendix II CITES. IOP Conference Series: Earth and Environmental Science, 374(1).

Fiqa, A. P. \& Oktavia, G. A. E. (2020). Plant Diversity and Composition of Three Different Altitudes in Sikka Forest Area-East Nusa Tenggara, Biosaintifika: 12(2), 192-202.

García-Roselló, E., Guisande, C., ManjarrésHernández, A., González-Dacosta, J., Heine, J., Pelayo-Villamil, P., Lobo, J. M. (2015). Can we derive macroecological patterns from primary Global Biodiversity Information Facility data? Global Ecology and Biogeography, 24(3), 335347.

GBIF Secretariat (2021). GBIF Backbone Taxonomy. Checklist dataset https://doi.org/10. 15468/39o mei ccessed via GBIF.org on 2021-06-15.

Harvey-Brown, Y. (2018). Aquilaria malaccensis. The IUCN Red List of Threatened Species 2018 Retrieved 11/14/2020, 2020, from https:// www.iucnredlist.org/species/32056/2810130

Herber, B. E. (2003).Thymelaeaceae. Flowering Plants Dicotyledons, 373-396. Berlin, Heidelberg: Springer.

Hou, D. (1960). Thymelaeaceae. In: Van Steenis,C.G.G.J. (ed.). Flora Malesiana Series I,
Vol 6. Groningen, The Netherlands: WolterNoordhoff Publishing.

Iryadi, R., Sutomo, \& Darma, I. D. P. (2021). Multistoried agroforestry system of Gaharu (Gyrinops verstegii (Gilg.) Domke) in Flores Island East Nusa Tenggara. In IOP Conference Series: Earth and Environmental Science (Vol. 648, No. 1, p. 012024). IOP Publishing.

Isnaini, Y. (2008). Mengenal tumbuhan penghasil Gaharu di Indonesia dan Koleksi Kebun Raya Bogor. Warta Kebun Raya, 8(2), 73-77.

IUCN. (2020). IUCN Red List Catagories and Criteria: Version 3.1. Retrieved 11/14/2020, 2020, from https://www.iucnredlist.org/

Karlinasari, L., Indahsuary, N., Kusumo, H. T., Santoso, E., Turjaman, M., \& Nandika, D. (2015). Sonic and ultrasonic waves in agarwood trees (aquilaria microcarpa) inoculated with fusarium solani. Journal of Tropical Forest Science, 27(3), 351-356.

Mulyaningsih, T., \& Yamada, I. (2007). Notes on some species of agarwood in Nusa Tenggara, Celebes and West Papua. Natural resource management and socio-economic transformation under the decentralization in Indonesia: Toward Sulawesi area studies, 365-372.

Mulyaningsih, T., Marsono, D., Sumardi, \& Yamada, I. (2017). Keragaman Infraspesifik Gaharu Gyrinops Versteegii (Gilg.) Domke Di Pulau Lombok Bagian Barat. Jurnal Penelitian Hutan Dan Konservasi Alam, 14(1), 57-67.

Praptosuwiryo, T. N. (2020). Assessing the conservation status of tree fern cibotium arachnoideum (C. chr.) holttum. Biodiversitas, 21(4), 1379-1384.

Qomariyah, N., Wirawan, R., Anggarani, N. K. N., Mardiana, L., \& Alhadi, K. (2019). Karakteristik Gaharu Grynops Vertegii (Gilg.) Domke Berdasarkan Analisis Sebaran Gray Scale Level.Eigen Mathematics Journal,1(1), 39-43.

Rindyastuti, R., Yulistyarini, T., \& Darmayanti, A. S. (2019). Population and ecological study of agarwood producing tree (Gyrinops versteegii) in Manggarai district, Flores island, Indonesia. Biodiversitas, 20(4), 1180-1191.

Roemantyo, R., \& Partomihardjo, T. (2010). Analisis Prediksi Sebaran Alami Gaharu Marga Aquilaria Dan Gyrinops Di Indonesia [Natural Distribution Prediction Analyses of Agarwood Genera of Aquilaria and Gyrinops in Indonesia]. Berita Biologi, 10(2), 68300.

Sitepu, I.R, Santoso, E., \& Turjaman, M. (2011). Identication of Eaglewood (Gaharu) Tree Species Susceptibility. Reserch and Development Centre for Forest Conservation and Rehabilitation. Badan 
Penelitian dan Pengembangan Kehutanan, Indonesia.

Sukenti, K., \& Mulyaningsih, T. (2019). Gaharu (Gyrinops versteegii (Gilg.) Domke) Di Pulau Sumbawa: Sebuah Tinjauan Etnobotani.Bio Wallacea Jurnal Ilmiah Ilmu Biologi,5(2), 62-68. .

Surata, K., \& Soenarno, S. (2011). Penanaman Gaharu (Gyrinopsversteegii (Gilg.) Domke) dengan SistemTumpangsari di Rarung, Provinsi Nusa Tenggara Barat. Jurnal Penelitian Hutan dan KonservasiAlam, 8(4), 349-361.

Susilo, A., Kalima, T., \& Santoso, E. (2014). Panduan Lapangan Pengenalan Jenis Pohon Penghasil Gaharu Gyrinops spp . di Indonesia. Bogor, Indonesia: Kementerian Kehutanan, Badan Penelitian dan Pengembangan Kehutanan, Pusat Penelitian dan Pengembangan Konservasi dan Rehabilitasi - International Tropical Timber Organization (ITTO).

Sutomo, Iryadi, R. (2019). Analisis Vegetasi, Struktur Kuantitatif Gyrinops verstegii dan Rekomendasi Area Budidayanya di Pulau Flores, NTT. Pages 359 in Rahajoe JS, Witjaksono, Sutrisno H,
Rahmadi C, eds. Seminar Nasional Konservasi dan Pemanfaatan Tumbuhan dan Satwa Liar. Bogor: LIPI.

Sutomo, Oktavia, G. (2019). Ekologi Jenis Penghasil Gaharu (Gyrinops versteegii) di Pulau Lombok Indonesia. Pages 93-101 in Semiadi G, Bismark $M$, eds. Seminar Nasional Konservasi dan Pemanfaatan Tumbuhan dan Satwa Liar. Bogor: Puslit Biologi LIPI.

Widodo, P., T. Chikmawati, et al. (2011). Distribusi dan Status Konservasi Syzygium zollingerianum (Miq.) Amsh. (Myrtaceae). Seminar Nasional HUT Kebun Raya Cibodas Ke-159. Cibodas Jawa Barat, UPT Balai Konservasi Tumbuhan Kebun Raya Cibodas.

Yulistyarini, T., Fiqa, A. P., Budiharta, S., \& Rindyastuti, R. (2020). Distribution of Gyrinops versteegii (Gilg.) Domke in varying vegetation structures, soil properties, and microclimates in Manggarai, Flores, East Nusa Tenggara. Biodiversitas Journal of Biological Diversity, 21(5) $1800-1808$. 